\title{
INFLUENCE OF NITROGEN FERTILIZER ON GRASS BIOMASS YIELD AND AMOUNT OF ENERGY GAINED PER AREA UNIT
}

\author{
Aleksandrs Adamovics ${ }^{1}$, Rasma Platace ${ }^{1}$, Inguna Gulbe ${ }^{2}$ \\ ${ }^{1}$ Latvia University of Life Sciences and Technologies, Latvia; \\ ${ }^{2}$ Institute of Agricultural Resources and Economics - "Priekuli", Latvia \\ aleksandrs.adamovics@1lu.lv, rasmins@inbox.lv, inguna.gulbe@arei.lv
}

\begin{abstract}
Sustainability of biomass is characterized by its composition, physical properties and other qualitative parameters such as the amount of area required for gaining a unit of biomass energy $-\mathrm{GJ} \cdot \mathrm{ha}^{-1} \cdot \mathrm{year}^{-1}-$, which strongly depends on the productivity (i.e., yields per area unit) of the managed ecosystem. Perennial grasses are essential for the agricultural production sector in Latvia. The nature and extent of winter damage on grasslands highly dependupon the climatic conditions, moreover, it influences both persistency and the yield. Scientists have found that plant biomass is one of the best sources that may be used for the production of solid biofuels. The field trials were carried out in sod calcareous soils in 2011-2014. The following grass cultivars were used: reed canary grass (Phalaris arundinaceae (L.) Raush.), festulolium_( $\times$ Festulolium Asch. \& Graebn.), timothy (Phleum pratense L.), meadow fescue (Festuca pratensis) Huds.), and tall fescue (Festuca arundinaceae Schreb.). Fertilizers applied: main fertilizer (F) $-\mathrm{P} 80 \mathrm{~K} 120 \mathrm{~kg} \cdot \mathrm{ha}^{-1}$; and six additional nitrogen fertilizers: F +30 , $\mathrm{F}+60, \mathrm{~F}+90, \mathrm{~F}+120, \mathrm{~F}+150$, and $\mathrm{F}+180 \mathrm{~kg} \cdot \mathrm{ha}^{-1} \mathrm{~N}$. In our study, the highest energy yield per 1 ha was obtained from tall fescue $\left(119.8 \mathrm{GJ} \cdot \mathrm{ha}^{-1}\right)$ and timothy $\left(145.3 \mathrm{GJ} \cdot \mathrm{ha}^{-1}\right)$, when $180 \mathrm{~kg} \cdot \mathrm{ha}^{-1}$ of nitrogen fertilizer were applied, which was $54 \%$ and $73 \%$ more, respectively, compared to the unfertilized plots.
\end{abstract}

Keywords: nitrogen, fertilizer, perennial grasses, energy yield.

\section{Introduction}

Grasses are an important crop group suitable for growing under agro-climatic conditions of Latvia, and they possess a small energy capacity. The production of grass biomass for fuel production is becoming increasingly popular in all Europe, and its introduction is lucrative for farmers. It takes only $70-80$ days to grow grass biomass for energy $[1 ; 2]$.

A survey of biomass supply in Europe showed that multi-year grasses had the highest biomass potential [3].

In 2007, the energy output from pure reed canary grass fields in Estonia amounted to $144 \mathrm{GJ} \cdot \mathrm{ha}^{-1}$, while in spring it was $116 \mathrm{GJ} \cdot \mathrm{ha}^{-1}$ [4]; whereas in Lithuania, pure reed canary grass fields produced an average of $115-130 \mathrm{GJ} \cdot \mathrm{ha}^{-1}[5]$.

At the conference of the Latvian Biogas Association, Andis Kārklinšs [6] referred to the data in Indulis Emsis' report: "There is the following amount of energy extraction possibilities from 1 ha per year in Latvia: forest (wood growth) - 26.8-33.5 GJ.ha ${ }^{-1}$; crop plants (biogas) - 100-150 GJ.ha ${ }^{-1}$; biodiesel (from rape seed) - 37-45 GJ.ha ${ }^{-1}$; and fuel bioethanol (from grains) - 27-36 GJ.ha' ${ }^{-1}$ ".

The objective of the study was to clarify how the energy value of grass biomass varies depending on the calorific value and dry matter yield of grasses.

\section{Materials and methods}

Field trials were set up at the study and research farm "Pēterlauki" $\left(56^{\circ} 53^{\prime} \mathrm{N}, 23^{\circ} 71^{\prime}\right.$ E) of the Latvia University of Life Sciences and Technologies (LLU) in 2011. Soil: sod calcareous soil LUVISOLS (according to the FAO classification). Granulometric composition: heavy dusty sand clay. Soil agrochemical parameters: pH KCL 6.7 (LVS ISO 10390: 2006); organic matter content $21 \mathrm{~g} \cdot \mathrm{kg}^{-1}$ (by Tyurin method; LV ST ZM 80-91); phosphorus content $-52 \mathrm{mg} \cdot \mathrm{kg}^{-1} \mathrm{P}_{2} \mathrm{O}_{5}$, and potassium content - $128 \mathrm{mg} \cdot \mathrm{kg}^{-1} \mathrm{~K}_{2} \mathrm{O}$ (according to the Egner-Rhym method; LV ST ZM 82-97).

The following grass cultivars were used: reed canary grass (Phalaris arundinaceae (L.) Raush.) cultivar "Marathon", festulolium_( $\times$ Festulolium Asch. \& Graebn.) cultivar "Vetra", timothy (Phleum pratense L.) cultivar "Teicis", meadow fescue (Festuca pratensis) Huds.) cultivar "Vaira", and tall fescue (Festuca arundinaceae Schreb.) cultivar "Fawn".

Grasses were sown in May 2011 without a cover crop, in three replications, within a $10 \mathrm{~m}^{2}$ plot size. 
Fertilizers applied: main fertilizer $(\mathrm{F})-\mathrm{P} 80 \mathrm{~K} 120 \mathrm{~kg} \cdot \mathrm{ha}^{-1}$; and six additional nitrogen fertilizers: $\mathrm{F}+30, \mathrm{~F}+60, \mathrm{~F}+90, \mathrm{~F}+120, \mathrm{~F}+150$, and F + $180 \mathrm{~kg} \cdot \mathrm{ha}^{-1} \mathrm{~N}$.

Nitrogen fertilizer was ammonium nitrate $\left(\mathrm{NH}_{4} \mathrm{NO}_{3}\right)$, phosphorus fertilizer was simple granular superphosphate $\left(\mathrm{Ca}\left(\mathrm{H}_{2} \mathrm{PO}_{4}\right) 2 \cdot \mathrm{H}_{2} \mathrm{O}+\mathrm{CaSO}_{4}\right)$, and potassium fertilizer was potassium chloride $(\mathrm{KCl})$. No mineral fertilizers were used in the sowing year.

The highest calorific value $(Q a)$ for different grass species was determined by the standard ISO 1928, LVS EN 14918 "The laboratory of waste and fuel exploration and testing "Virsma"“ in five replications for each species. The highest calorific value of grass and wood biomass was used to calculate the amount of the energy produced. The energy value of pellets was calculated using the following formula [7] (1):

$$
Q_{\text {kop }}=Q_{a} \cdot M_{s},
$$

where $Q_{k o p}$ - total amount of energy obtained from 1 ha, MJ $\cdot \mathrm{ha}^{-1}$;

$Q_{a}$ - highest calorific value of biomass dry matter, $\mathrm{MJ} \cdot \mathrm{kg}^{-1}$;

$M_{s}$ - mass of biomass dry matter of $1 \mathrm{ha}, \mathrm{kg} \cdot \mathrm{ha}^{-1}$.

\section{Results and Discussion}

Compared to fossil resources, biomass is the cheapest raw material for fuel [8]. Most useful for energy production are crops that produce high dry matter yields $\left(\mathrm{t} \mathrm{ha}^{-1}\right)$ at low costs $[9 ; 10]$.

Dry matter yield depends on the use of nitrogen fertilizer. A significant yield increase for canary reed grass, meadow fescue and tall fescue was obtained using $60 \mathrm{~kg} \cdot \mathrm{ha}^{-1}$ of $\mathrm{N}$, for festulolium $90 \mathrm{~kg} \cdot \mathrm{ha}^{-1}$ of $\mathrm{N}$, and for timothy $-120 \mathrm{~kg} \cdot \mathrm{ha}^{-1}$ of $\mathrm{N}$ when background PK fertilization was $80 \mathrm{~kg} \cdot \mathrm{ha}^{-1}$ of $\mathrm{P}_{2} \mathrm{O}_{5}$ and $120 \mathrm{~kg} \cdot \mathrm{ha}^{-1}$ of $\mathrm{K}_{2} \mathrm{O}$ (Table 1 ).

Table 1

Influence of nitrogen fertilizer on grass dry matter yield (average in 2012-2014)

\begin{tabular}{|c|c|c|c|c|c|c|c|c|}
\hline \multirow{3}{*}{$\begin{array}{l}\text { N norms, } \\
\text { kg }^{-h^{-1}}\end{array}$} & \multicolumn{7}{|c|}{ Dry matter yield, $t^{\prime} \cdot \mathrm{h}^{-1}$} & \multirow{3}{*}{$\begin{array}{c}\text { Relative } \\
\text { variation of } \\
\text { yield, \% }\end{array}$} \\
\hline & \multicolumn{5}{|c|}{ Grass species } & \multirow[b]{2}{*}{ Average } & \multirow[b]{2}{*}{$S x$} & \\
\hline & $\begin{array}{c}\text { reed canary } \\
\text { grass }\end{array}$ & festulolium & timothy & $\begin{array}{c}\text { meadow } \\
\text { fescue }\end{array}$ & $\begin{array}{c}\text { tall } \\
\text { fescue }\end{array}$ & & & \\
\hline 0 & 5.20 & $4.89^{\mathrm{c}}$ & $4.96^{\mathrm{c}}$ & $4.52^{\mathrm{c}}$ & 5.11 & 4.94 & \pm 0.12 & 100 \\
\hline 30 & $6.09^{\mathrm{a}}$ & $5.64^{\mathrm{a}, \mathrm{c}}$ & $5.86^{\mathrm{a}, \mathrm{c}}$ & $5.39^{\mathrm{a}, \mathrm{c}}$ & $5.74^{\mathrm{a}, \mathrm{c}}$ & 5.74 & \pm 0.12 & 116 \\
\hline 60 & $7.01^{\mathrm{a}}$ & $6.45^{\mathrm{a}, \mathrm{c}}$ & $6.79^{\mathrm{a}, \mathrm{c}}$ & $6.22^{\mathrm{a}, \mathrm{c}}$ & $6.31^{\mathrm{a}, \mathrm{c}}$ & 6.56 & \pm 0.15 & 133 \\
\hline 90 & 6.95 & $7.09^{\mathrm{a}}$ & $7.52^{\mathrm{a}, \mathrm{b}}$ & $6.57^{\mathrm{c}}$ & $6.52^{c}$ & 6.93 & \pm 0.18 & 140 \\
\hline 120 & 7.28 & 7.32 & $8.06^{\mathrm{a}, \mathrm{b}}$ & 7.15 & 7.13 & 7.39 & \pm 0.17 & 150 \\
\hline 150 & 7.54 & $7.74^{b}$ & $8.23^{\mathrm{b}}$ & 7.64 & 7.45 & 7.72 & \pm 0.14 & 156 \\
\hline 180 & 7.94 & $8.30^{\mathrm{b}}$ & $8.60^{b}$ & $8.13^{\mathrm{b}}$ & 7.88 & 8.17 & \pm 0.13 & 166 \\
\hline Average & 6.86 & 6.78 & 7.15 & 6.52 & 6.59 & 6.78 & \pm 0.11 & $x$ \\
\hline$S x$ & \pm 0.35 & \pm 0.45 & \pm 0.51 & \pm 0.48 & \pm 0.37 & \pm 0.43 & \pm 0.19 & 0.19 \\
\hline
\end{tabular}

Notes: a - significant increase in yield by increasing the nitrogen norm by $30 \mathrm{~kg} \cdot \mathrm{ha}^{-1}$;

$\mathrm{b}$ - significant increase in yield compared to reed canary grass;

$\mathrm{c}$ - significant reduction in yield compared to reed canary grass.

From the grasses included in the study, the highest calorific value of the first cut biomass varied from 15.20 MJ $\cdot \mathrm{kg}^{-1}$ for tall fescue to $16.90 \mathrm{MJ} \cdot \mathrm{kg}^{-1}$ for timothy (Table 2).

The highest calorific values of the biomass of reed canary grass and festulolium did not differ significantly, whereas differences among all other grass species were significant. The smallest biomass calorific values were observed in meadow fescue and tall fescue.

Gross calorific value $(Q)$ for different grass species, $\mathbf{M J} \cdot \mathbf{k g}^{-1}$

Table 2

\begin{tabular}{|c|c|c|c|c|c|c|}
\hline $\begin{array}{c}\text { Reed } \\
\text { canary grass }\end{array}$ & Festulolium & Timothy & $\begin{array}{c}\text { Meadow } \\
\text { fescue }\end{array}$ & Tall fescue & Average & $\boldsymbol{S x}$ \\
\hline 16.40 & 16.50 & 16.90 & 15.70 & 15.20 & 16.14 & \pm 0.30 \\
\hline
\end{tabular}


The sustainability of biomass as an energy carrier is characterized not only by the parameters of the biomass economic properties and quality, but also by its energetic assessment.

The amount of energy from different grasses was directly dependent on their dry matter yield (Figures 1 and 2).

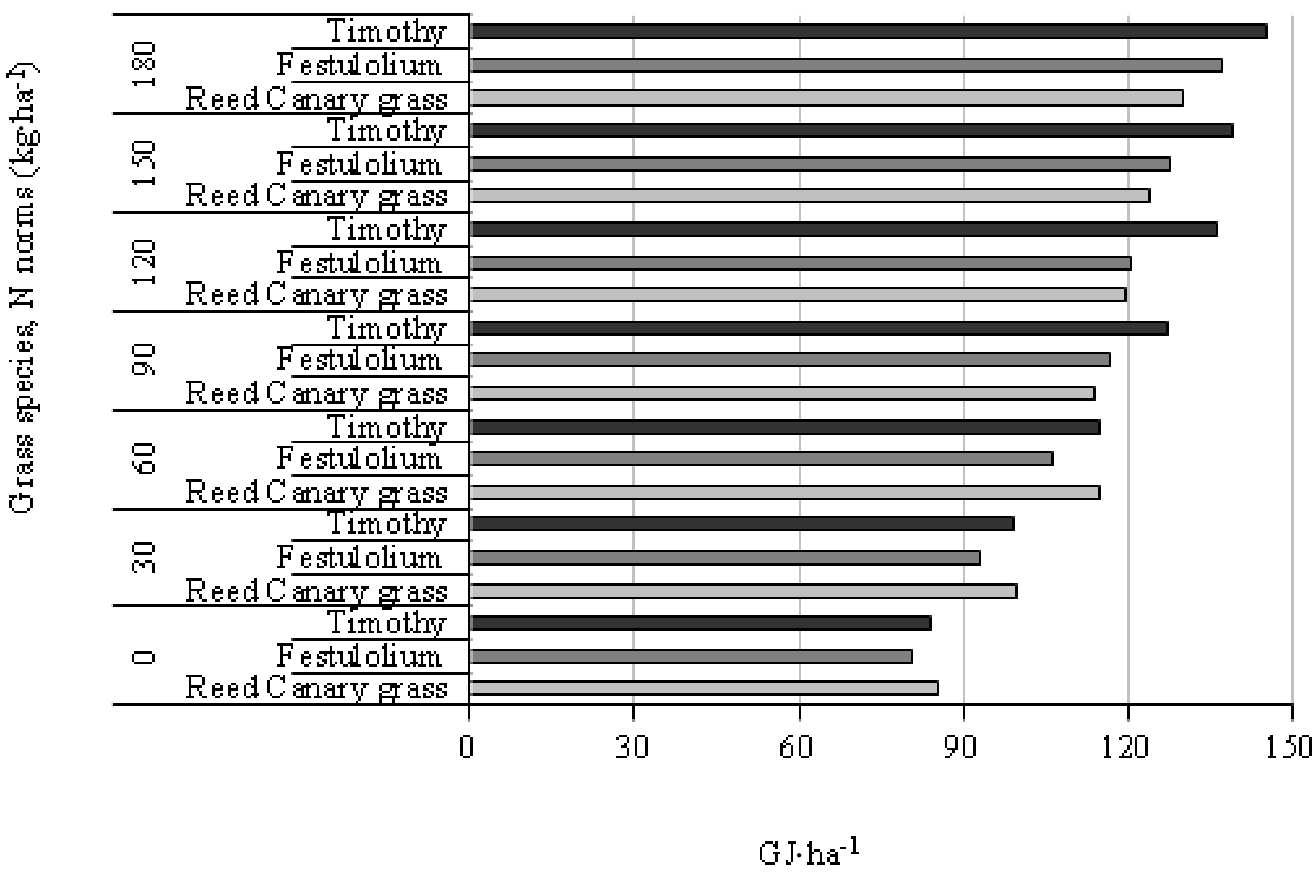

Fig. 1. Impact of nitrogen fertilizer norms on energy benefit from reed canary grass, festulolium and timothy (average in 2012-2014)

The amount of energy obtained in the non-nitrogen fertilizer variant with the phosphorus and potassium (P80K120) fertilizer background from 1 ha varied from $71.0 \mathrm{GJ} \cdot \mathrm{ha}^{-1}$ for meadow fescue to $85.3 \mathrm{GJ} \cdot \mathrm{ha}^{-1}$ for reed canary grass.

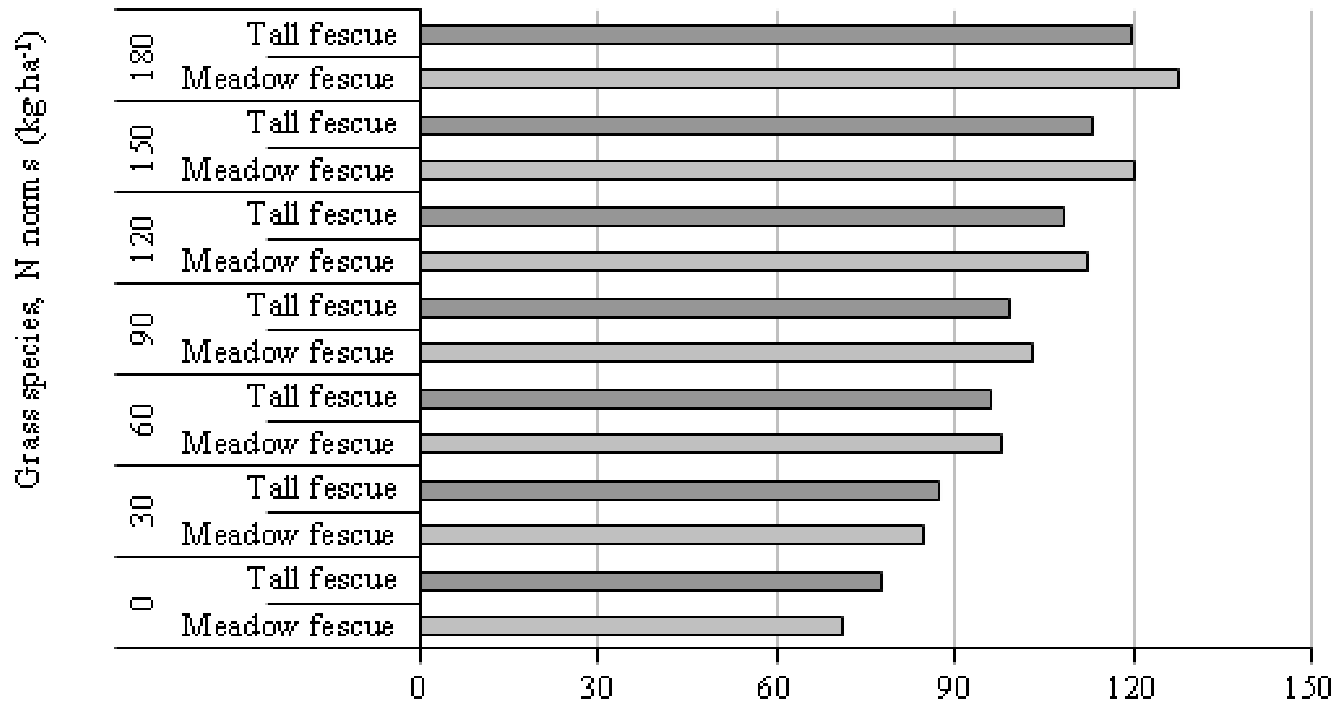

GJ.ha-1

Fig. 2. Impact of nitrogen fertilizer rates on amount of energy obtained from meadow fescue and tall fescue (average in 2012-2014) 
Nitrogen fertilizers contributed not only to the increase in the dry matter yield, but also to the amount of the energy produced. On average, the amount of energy from 1 ha of all nitrogen standard variants varied from $103.9 \mathrm{GJ} \cdot \mathrm{ha}^{-1}$ for tall fescue to $126.9 \mathrm{GJ} \cdot \mathrm{ha}^{-1}$ for timothy with respective increase of $34-51 \%$ compared to the non-nitrogen fertilizer variant. The largest amount of energy received from 1 ha was detected in the variant with a nitrogen norm of $180 \mathrm{~kg} \cdot \mathrm{ha}^{-1} \mathrm{~N}$ : from $119.8 \mathrm{GJ} \cdot \mathrm{ha}^{-1}$ ( $+54 \%$ compared to the non-nitrogen fertilizer variant) for tall fescue to $145.3 \mathrm{GJ} \cdot \mathrm{ha}^{-1}$ for timothy ( $+73 \%$ compared to non-nitrogen fertilizer).

\section{Conclusions}

1. Significant yield increases were obtained using the following nitrogen fertilizer norms: $60 \mathrm{~kg} \cdot \mathrm{ha}^{-1}$ of $\mathrm{N}$ for reed canary grass, meadow fescue and tall fescue, $90 \mathrm{~kg} \cdot \mathrm{ha}^{-1}$ of $\mathrm{N}$ for festulolium, and $120 \mathrm{~kg} \cdot \mathrm{ha}^{-1}$ of $\mathrm{N}$ for timothy.

2. From the first cut, the highest calorific value for grass biomass varied from $15.20 \mathrm{MJ} \cdot \mathrm{kg}^{-1}$ for tall fescue to $16.90 \mathrm{MJ} \cdot \mathrm{kg}^{-1}$ for timothy. The lowest calorific value was detected for the biomass of meadow fescue and tall fescue.

3. The greatest amount of energy from 1 ha was obtained applying the nitrogen norm of $180 \mathrm{~kg} \cdot \mathrm{ha}^{-1}$ : $119.8 \mathrm{GJ} \cdot \mathrm{ha}^{-1}$ for tall fescue and $145.3 \mathrm{GJ} \cdot \mathrm{ha}^{-1}$ for timothy.

\section{Acknowledgements}

The research was supported by the grant of the Ministry of Agriculture of the Republic of Latvia.

\section{References}

[1] A., Dubrovskis V., Plūme I. etc. Biomasas izmantošanas ilgtspējības kritēriju pielietošana un pasākumu izstrāde (Application of biomass sustainability criteria and development of measures.). Valsts SIA „Vides projekti”. Rīga, 2009. 186 lpp.

[2] Slepetys J., Kadziuliene Z., Sarunaite L. etc. Biomass potential of plants grown for bioenergy production. Proceedings of International Scientific conference "Renewable Energy and Energy Efficiency". Jelgava, Latvia, 2012. p. 66 -72.

[3] Ericsson K., Nilsson L.J. Assessment of the potential biomass supply in Europe using a resource-focused approach. Biomass and Bioenergy, No. 30, 2006. p. 1-15.

[4] Heinsoo K., Hein K., Melts I. etc. Reed canary grass yield and fuel quality in Estonian farmers' fields. Biomass and Bioenergy, No. 35, issue 1, 2011. p. 617-625.

[5] Jasinskas A., Zaltauskas A., Kryzeviciene A. The investigation of growing and using of tall perennial grasses as energy crops. Biomass and Bioenergy, No. 32, 2008. p. 981-987.

[6] Latvijas energoneatkarība un biogāzes vieta tajā (Latvian biogas energy independence and place in it) 19.03.2011, Rīga, 20. Zaḷās partijas kongress, (In Latvian). [online] [11.01.2018]. Available at: $\quad$ ihttps://www.slideshare.net/ligastala/biogazes-izmantoana-andis-krkli

[7] Kaķīis A., Šmits M., Belicka I. (2009). Suitability of crop varieties for energy production. Engineering for Rural Development. Proceedings of the $8^{\text {th }}$ International Scientific Conference, May 28 - 29, 2009. Jelgava, p. 188-193.

[8] Fernández R. G., García C. P., Lavín A. etc. Study of Main Combustion Characteristics for Biomass Fuels Used in Boilers. Fuel Processing Technology, No. 103, 2012. p. 16 -26.

[9] Demibras A. Biomass resource facilities and biomass conversion processing for fuels and chemicals. Energy Conversion and Management, No. 42, 2001. p. 1357-1378.

[10] Demibras A. Combustion characteristics of different biomass fuels. Progress in Energy and Combustion Science, No. 30, 2004. p. 219-230. 